Зінаӥда СВЯЩЕНКО,

orcid.org/0000-0001-5845-3115

доктор історичних наук, професор кафедри всесвітньої історії та методик навчання

Уманського державного педагогічного університету імені Павла Тичини

(Украӥна, Умань)

szv09@meta.ua

\title{
МІСЦЕ МОЗАМБІКУ У ВІЙСЬКОВО-ПОЛІТИЧНІЙ СТРАТЕГІЇ СРСР НА ПІВДНІ АФРИКИ
}

\begin{abstract}
В статті проаналізовано місие Мозамбіку у військово-політичній стратегії СРСР на півдні Африки, звертається увага на ідеологічні мотиви зовнішньополітичних акцій Радянського Союзу. Зазначається, щзо свій вплив на Африканському континенті СРСР намагався поширювати насамперед за допомогою комбінацій політико-дипломатичних зусиль, економічної допомоги та поставок зброї.

Зроблено висновок, щзо наприкіниі 1980-х рр. Мозамбік залишався одним з найбільш відданих союзників Москви в Африці. Надаючи Мозамбіку допомогу у будівництві збройних сил, радянські лідери прагнули будьякою иіною утримати його в сфері свого впливу. Серед причин слід вказати, передусім, геополітичні фактори, а саме - можливість впливати на сусідню Південну Африку. Крім того, радянський флот мав потребу у базах на західноафриканському узбережжі.
\end{abstract}

Ключові слова: Мозамбік, СРСР, вплив, поставки зброї, радянська військова присутність.

Zinaida SVYASCHENKO,

Doctor of Historical Sciences, Associate Professor of World History and methods of Teaching Uman State Pedagogical University Paul Tychiny

(Ukraine, Uman),

szv09@meta.ua

\section{THE PLACE OF MOZAMBYK IN THE MILITARY-POLITICAL STRATEGY OF THE USSR ON SOUTH AFRICA}

The article analyzes the place of Mozambique in the military-political strategy of the USSR in southern Africa. It is noted that its influence on the African continent of the USSR was aimed primarily at the use of combinations of political and diplomatic efforts, economic assistance and arms supplies. The cooperation between the USSR and the African states from the outset was deeply ideological.

The purpose of the proposed study is to show the place of Mozambique in the military-political strategy of the USSR in southern Africa, paying attention to the ideological motives of foreign-policy actions. The research is based on such principles of historical knowledge as science, historicism, objectivity, systematic analysis, etc.

The volume and character of the military and economic assistance of the USSR to Mozambique have been analyzed, which has been shown in the strengthening the country's defense capability and effectively created the Mozambican Armed Forces. Soviet officers created the General Staff, formed and prepared the main types of armed forces and forces of troops. Such forms of cooperation as the exchange of military delegations at all levels, mutual consultations with political bodies and armies have become widespread. The armed forces of the country received Soviet technique, specialists in working with this technique. Deliveries were made on preferential terms. The staff was trained at the training centers of the USSR.

However, it is noted that the result of this assistance was that the Government of Mozambique declared the choice of the socialist path of development, as reflected in the new name of the country (People's Republic of Mozambique), and soon the relevant transformations began: nationalization of the main segments of the economy, carrying out an agrarian reform. In addition, in exchange for assistance, FRELIMO provided the Soviet navy with access to the deep-water Gulf near Maputo, which is very convenient for the creation of a submarine base. 
The socialist bloc also received the right of privileged access to the natural resources of the republic. It is concluded that in the late 1980's Mozambique remained one of the most loyal allies of Moscow in Africa. By giving Mozambique assistance in building the armed forces, Soviet leaders sought at any cost to keep it in the sphere of his influence. Among the reasons, it should be noted, above all, geopolitical factors, namely, the possibility of influencing neighboring South Africa. Besides, the Soviet fleet was in need of bases on the West African coast. However, the situation has changed as a result of the changes in Moscow itself - liberalization, reconstruction, and then the collapse of the USSR forced it to abandon its interests and to stop subsidies of the Union regimes.

Key words: Mozambique, USSR, influence, supply of weapons, Soviet military presence.

Постановка проблеми. Наприкінці 1950-х рp., коли в Центральній і Південній Африці почалися масові рухи за національну незалежність і суверенітет, Радянський Союз став на сторону тих керівників, які разом 3 антиколоніальними гаслами висували ідеї побудови «суспільства без класів і приватної власності». Свій вплив на Африканському континенті СРСР намагався поширювати насамперед за допомогою комбінацій політикодипломатичних зусиль, економічної допомоги та поставок зброї.

Співпраця між СРСР і африканськими державами 3 самого початку носила глибоко ідеологічний характер. Переважала думка, що спочатку слід зміцнити владу, а вже потім братися за радикальні суспільні перетворення, інакше влада може бути втрачена. Тому Москва надавала великого значення постачанню в країни Африки зброї, яке, правда, не завжди «спрацьовувало» в напрямку, бажаному СРСР. Однією із країн Африки, де мала місце радянська військова присутність є Мозамбік.

Аналіз досліджень. Окреслена тема опосередковано порушувалась у працях вітчизняних та зарубіжних дослідників, присвячених участі Радянського Союзу у локальних війнах і конфліктах після Другої світової війни. Серед них слід назвати праці С.Я. Лавреїнова і І.М. Попова (Лавреинов, Попов, 2005), С.А. Коломніна (Коломнин, 2005) та колективні дослідження (Россия и СССР, 2001; Россия (СССР) в локальных войнах, 2000), в яких дослідники аналізують участь СРСР у ряді збройних конфліктів, які мали місце в різні періоди його історії, звертаючи значну увагу на африканський континент. Серед досліджень співпраці між СРСР і Мозамбіком значне місце посідають роботи В.I. Шарого (Шарый, 2008). Місцю Мозамбіку у протистоянні США та СРСР на півдні Африки (1975 - 1991 рр.) присвячена праця Д.С. Крисенка (Крисенко), автор 
робить висновок, що наприкінці 1980-х рр. Мозамбік залишався одним 3 найбільш відданих союзників Москви в Африці.

Мета статті. Метою дослідження $є$ показати місце Мозамбіку у військово-політичній стратегії СРСР на півдні Африки, звернувши увагу на ідеологічні мотиви зовнішньополітичних акцій Радянського Союзу.

Виклад основного матеріалу. Початок національно-визвольного руху в Мозамбіку припав на середину 1950-х рp. Перші патріотичні організації мозамбіцькі емігранти створили в сусідніх африканських країнах. У 1962 р. вони об'єдналися в єдиний Фронт визволення Мозамбіку (ФРЕЛІМО) зі штабквартирою у Дар-ес-Саламі (Танзанія). Очолив організацію Едуардо Мондлане (1920-1970), емігрант із Мозамбіку, що працював професором антропології Сіракузького університету в США. Незважаючи на виховання в методистській місіонерській школі, академічну освіту, захищену дисертацію та поважну посаду, Е. Мондлане був переконаним прихильником збройної боротьби за незалежність. До керівництва угрупування входили Самора Машел, Марселіно Сантуш, Жоаким Чісано, Паскуаль Мокумбі, Серхіо Вейра, Оскар Монтейру, Акіно де Браганса та Хорхе Ребело. Між цими лідерами йшла дискусія про характер та курс держави, яка мала з'явитися після перемоги над португальцями.

Питання стояло між чорним націоналізмом та радикальним марксизмом. У лютому 1969 р. Е. Мондлане, який схилявся до першого варіанту, був убитий. Його місце посів С. Машел, який перетворився на одного 3 найближчих союзників СРСР у Африці. На межі 1960-х - 1970-х рр. Кремль морально підтримував його та надавав безкоштовну матеріальну допомогу. Сильними також були зв'язки ФРЕЛІМО з Кубою, які існували з початку 1960-х рр. У січні 1966 р. ФРЕЛІМО взяло участь у конгресі трьох континентів у Гавані, де Фідель Кастро організував зустріч представників революційних рухів 3 усього світу. Також значна частина активістів зазначеної організації пройшла на Кубі військову підготовку. До іiі підтримки також долучилися інші прорадянські 
фронти східного блоку, у тому числі Всесвітня Рада Миру та Солідарності (Крисенко).

Тим часом, зміни відбувалися і у самій метрополії, де посилювалася опозиція до керівника країни Марселу Каетану, який продовжував правоконсервативний курс А. Салазара. У квітні 1974 р. в Португалії відбулася «революція гвоздик», нове керівництво країни вирішило відмовитися від своїх африканських колоній, тому просто передали владу ФРЕЛІМО, без яких би то не було виборів. Отже, 25 червня 1975 р. загони ФРЕЛІМО тріумфально увійшли до столиці Мапуту, Мозамбік отримав незалежність. С. Машел здобув перемогу на президентських виборах, привівши до влади і свою партію.

Після завоювання влади нове керівництво африканських держав в першу чергу повинно було подбати про сильну армію для утримання цісї влади. Вибір для іï форсованого формування та оснащення був обмежений і зводився до простої формули: Радянський Союз або США. Визначившись $з$ покровителем, африканські союзники, користуючись підтримкою наддержав, нерідко намагалися вирішити на свою користь проблеми, що накопичилися в міждержавних відносинах. У тому числі збройним шляхом. Тоді в орбіту кризи неминуче втягувалися держави-важковаговики (Лавреинов, 2005: 370). Так було і з Мозамбіком, який віддав перевагу СРСР.

До того часу, як у травні 1976 р. С. Машел відвідав Москву, він уже підписав договори про дружбу та співпрацю з Болгарією, Чехословаччиною, Румунією та КНДР. Радянські лідери наголосили, що, перед підписанням аналогічного договору він має продемонструвати свою відданість марксизмуленінізму, перетворивши свій рух на комуністичну партію. В якості підтвердження своїх намірів, Москва підписала з ним угоду про поставки зброї. С. Машел прийняв ці умови, і на спеціальному з'їзді у лютому 1977 p. перетворив свій «визвольний рух на повноцінний авангард комуністичної партії проти феодалізму та колоніалізму», розкритикувавши капіталізм як найбільш виражену форму експлуатації людини людиною. Події у Мозамбіку явили собою черговий успіх радянської дипломатії - до того, спеціалісти з СРСР вже 
перебували на території ще декількох африканських країн - Анголи, Ефіопії та Конго (Россия и СССР в войнах, 2001: 336).

У 1977 р. сторони підписали Договір про дружбу та співробітництво терміном на 20 років (Договір). Після його підписання уряд Мозамбіку заявив про вибір соціалістичного шляху розвитку, що було відображено у новій назві країни (Народна Республіка Мозамбік), і незабаром розпочав відповідні перетворення: націоналізував основні сегменти економіки, провів аграрну реформу.

Під управлінням марксистів країна жила постійними кампаніями. 1976 p. оголошено «роком зростання виробництва», 1978 р. - «розбудови партійної організації», 1980 р. - «наступу на корупцію», 1982 - 1983 рр. - «роками продукції» тощо.

Першочерговим завданням мозамбікців було зміцнення обороноздатності, тому значного поширення набули такі форми співпраці, як обмін військовими делегаціями на усіх рівнях, проведення взаємних консультацій з політорганами та арміями. Перша офіційна група радянських військових радників прибула в Мапуту в 1976 р. Завдання було поставлене гранично просто. Створити Збройні сили Мозамбіку (Война которой не было).

У 1978 р. МО СРСР направило у Мозамбік першого заступника міністра оборони СРСР з офіційним візитом. Збройні сили країни отримали радянську техніку (серед якої були літаки МіГ-21, вертольоти Мi-24 і танки Т-54/55), а разом з нею туди поїхали фахівці по роботі з цією технікою. Персонал пройшов підготовку в навчальних центрах СРСР. Мозамбікські льотчики для транспортної авіації теж були підготовлені в СРСР. Так само, як і екіпажі вертольотів.

Поставки здійснювалися на пільгових умовах розрахунків з оплатою $50 \%$ вартості, у кредит на 8-10 років під 3\% річних. До 1991 р. загальна вартість поставленого спецмайна склала 1153 млн. крб., інші витрати оцінювалися у 1209 млн. крб. (Шарый, 2008: 19). 
Радянськими офіцерами був створений Генеральний штаб, сформовані і підготовлені основні види збройних сил і родів військ. У той же час радянськими фахівцями було створено перше військове училище Мозамбіку у місті Нампулі, навчальний центр в місті Накале, навчальний центр прикордонних військ в місті Іньямбане, навчальний центр молодших авіаційних фахівців в місті Бейрі, автомобільна школа в місті Мапуту.

Вже до 1980 p. було розгорнуто 4 прикордонних бригади, 5 загальновійськових бригад. Розгорнуто зенітно-артилерійські і зенітно-ракетні дивізіони. Крім цього, були створені абсолютно нові для Африки радіотехнічні батальйони для захисту столиці країни (Война которой не было).

Велику роботу радянські офіцери виконали для створення протиповітряної оборони Мозамбіку. Поряд 3 зенітно-артилерійськими дивізіонами вони допомогли розгорнути ракетні дивізіони та радіотехнічні батальйони, що забезпечили протиповітряну оборону столиці Мозамбіку.

Угоди про військове співробітництво між СРСР і Мозамбіком передбачали, що радянські військові радники і фахівці не повинні мати особистої зброї і брати участь в бойових діях. Тільки в середині 1980-х рр., коли обстановка в країні ще більше загострилася, їм було дозволено тримати зброю на квартирах. Проте для радянських радників і фахівців загроза опинитися в бойовій ситуації існувала постійно. Траплялося так, що їм доводилося брати участь в сутичках, потрапляти під бомбардування і обстріл (Война которой не было).

Надаючи Мозамбіку допомогу у будівництві збройних сил, радянські лідери прагнули будь-якою ціною утримати його в сфері свого впливу. Серед причин слід вказати, передусім, геополітичні фактори, а саме - можливість впливати на сусідню Південну Африку. Крім того, радянський флот мав потребу у базах на західноафриканському узбережжі. Після війни на Африканському Розі, в ході якої СРСР став на бік Ефіопії, вхід до сомалійських портів Індійського океану був для нього закритий. Тому в обмін на допомогу, ФРЕЛІМО надав радянському військово-морському флоту доступ до 
глибоководної затоки поблизу Мапуту, вельми зручної для створення бази підводних човнів (Россия и СССР в войнах, 2001: 406).

Соціалістичний блок також отримав право привілейованого доступу до природніх ресурсів республіки. Крім СРСР, основними зовнішньоекономічними партнерами Мозамбіку стали Куба, НДР, Румунія та Болгарія. Серед основних статей експорту слід вказати рибу, продукти сільського господарства (горіх кеш’ю, цитрусові та тропічні фрукти, маніок, тютюн, кава, бавовна) та вугілля. Валюта отримана від торгівлі цими продуктами, здебільшого йшла на оплату військових поставок.

Втім, порівняно із Анголою, Мозамбік все ж мав меншу пріоритетність: якщо на території першої впродовж періоду 1975 - 1991 рр. побували 12 тис. радянських військовослужбовців, то на території другого - утричі менше. Проте, вони взяли участь у більшості антиповстанських операцій уряду, про що свідчила наявність втрат, які за офіційними даними, склали 21 людину (Гриф секретности, 1993: 365). Серед загиблих у Мозамбіку були і українці. Серед них:

- Денисенко Валерій Михайлович, 1952 року народження. Старший лейтенант, фахівець-інструктор по експлуатації засобів зв'язку в збройних силах Мозамбіку. Загинув 26 лютого 1979 р.

- Заславець Микола Васильович, 1939 року народження. Підполковник, радник командира мотопіхотної бригади збройних сил Мозамбіку. Загинув 26 липня 1979 р Нагороджений орденом Червоної Зірки (посмертно).

- Ступак Роман Опанасович, 1942 року народження. Майор технічної служби, фахівець при заступнику командира змішаного артилерійського дивізіону збройних сил Мозамбіку по артилерійського озброєння. Помер від ран 20 березня 1978 р. (Война которой не было).

Новий уряд мав чимало противників, найбільшим центром тяжіння яких став «Національний опір Мозамбіку» (більше відомий за своїм португаломовним акронімом РЕНАМО). 22 тисячі іï прозахідно орієнтованих бойовиків вели партизанську війну проти властей та контролювали частину 
північних і центральних провінцій республіки. Цей рух був створений у квітні 1977 р. діячем Андре Матсангесе, - здебільшого, з числа кримінальних елементів та португальських емігрантів.

Значну роль у становленні організації відіграли спецслужби Південної Африки та Родезії (нині Зімбабве). ФРЕЛІМО, в свою чергу, також вело проти останніх опосередковану боротьбу, підтримуючи їхню опозицію. До цього слід додати, що Мапуту надавав допомогу прорадянським повстанцям в усіх країнах регіону (Крисенко).

Свою політичну платформу РЕНАМО вперше представила 19 серпня 1981 p. По суті, це був проект конституції для постФРЕЛІМОвського Мозамбіку. Сім ii розділів були присвячені економіці, охороні здоров'я та освіті, комунальним послугам і зовнішній політиці. Втім, проголошені тези демократії та прав людини майже не знаходили відгуку серед широких верств населення. Після того, як Матсангесе був убитий, а його місце посів Афонсу Длакама, тактика РЕНАМО зводилася до диверсій з тенденцією до максимізації економічних збитків.

Крім того, Мозамбік мав і інші проблеми - йшла ломка механізмів соціальної інерції, на яких трималися колоніальні інститути, заохочувалася народна активність, що здебільшого мала руйнівний характер. Передусім вона заторкувала сферу господарювання, яка залишалася частиною загальносвітової капіталістичної системи - мігранти з Мозамбіку складали чверть робітників на копальнях Південної Африки (Шинкарёв, 1989: 40-41).

Отже, Мапуту довелося вибирати між політикою протистояння Південній Африці і економічною залежністю від неї. Ситуація ускладнювалася наявністю у регіоні інтересів ще одного світового гравця - Сполучених Штатів. Держдепартамент прагнув «відлучити» ФРЕЛІМО від радянського блоку, запропонувавши йому політичну, дипломатичну та економічну допомогу. У першій половині 1980-х рр. Мозамбіку були надані кредити на суму понад 200 млн. дол. (Крисенко). Крім того, розрахунок робився на дрейф Мозамбіку у бік США - через посилення тиску ПАР та опікуваного нею РЕНАМО. 
Тим часом, в економіці Мозамбіку наростали економічні труднощі, С. Машел подавав прохання про вступ Мозамбіку до Ради економічної взаємодопомоги. Крім того, С. Машел звернувся по допомогу і до Заходу. У США розраховували, що С. Машел, прийнявши західну економічну допомогу, можливо, відмовиться від своїх зв'язків з СРСР. Крім пропозиції економічної допомоги, було розпочато дипломатичну кампанію, спрямовану на підписання договору між Мозамбіком і Південною Африкою.

Втім, поворот Мозамбіку у бік Заходу не був остаточним. Уряд С. Машела ніколи не відмовлявся від своїх переконань та зв'язків з СРСР. Як і більшість лідерів країн що розвивалися, С. Машел меншою мірою піклувався про реорганізацію національної економіки, ніж про досягнення та підтримання військової потуги, необхідної для утримання та консолідації влади.

Отже, економічна i дипломатична допомога 3 боку Заходу не була сигналом про послаблення союзу з радянським блоком. Зважаючи на це, США здійснили спробу фізичної ліквідації С. Машела, яка виявилася успішною. У 1986 р. відбулася авіакатастрофа, внаслідок якої він загинув. Проведене у березні 1987 р. розслідування показало, що південноафриканські наземні засоби за підтримки ЦРУ цілеспрямовано збили з курсу та спричинили падіння літака С. Машела. Його місце посів Жоаким Чіссано, який підтвердив відданість марксизму-ленінізму та радянському блоку. Посол Мозамбіку у Лондоні заявив про те, що «Мозамбік не переходить від однієї сторони до іншої, зі сходу на захід. Радянський Союз є нашим історичним союзником». Зважаючи на це, СРСР прискорив поставки зброї, і одразу після загибелі Машела до країни прибули два батальони кубинських сил, ще п’ять - після інаугурації Чиссано. Військова домовленість була поновлена, i Мозамбік підписав 3 СРСР п’ятирічний план оновлення парку більш сучасними літаками МіГ-23 та важкими танками Т-62. На свою чергу, СРСР підтвердив право використання портів Накала та Мапуту (Крисенко).

В той же час тривала громадянська війна в Мозамбіку і впродовж наступних десяти років інтенсивність боїв збільшилася. Зважаючи на це, в ході 
візиту до Москви у жовтні 1989 р., делегація ФРЕЛІМО, на чолі з членом Політбюро ЦК партії М. Матсіньє, зверталася 3 проханням про надання допомоги у зміцненні матеріальної бази військово-повітряних сил - поставкам нової техніки та запчастин, забезпеченні ремонту раніше поставленої техніки на суму 58 млн. дол. (Шарый, 2008: 19-20).

Конкретно йшлося про вирішення таких питань:

- про прискорення виконання в повному обсязі Радянської Стороною зобов'язань за діючими контрактними документами про постачання запасних частин для авіаційної техніки і ремонті авіаційного майна в СРСР;

- про надання більш пільгових умов розрахунків для закупівлі в СРСР вертольотів Mi-17 та проведення ремонту в СРСР вертольотів Mi-25, а також про передачу технічної документації на виготовлення в Мозамбіку контейнерів для перевезення вертольотів Мi-25 на ремонт в СРСР морським транспортом або про забезпечення ремонту цих вертольотів в Мозамбіку;

- про проведення ремонту в СРСР в 1990 - 1995 рр. 450 одиниць раніше поставленої авіаційної техніки та майна на суму понад 58 млн. доларів США (Шарый).

В цілому, якщо говорити про військово-технічне співробітництво СРСР 3 Мозамбіком, то воно в повному обсязі почало здійснюватися з 1975 р. Що ж стосується періоду боротьби за незалежність з 1964 по 1975 рр., то Радянський Союз надавав ФРЕЛІМО в цей період допомогу зброєю і спорядженням на безоплатній основі. Загальний обсяг цих поставок склав близько 2,2 млн. рублів (Шарый).

Політика США щодо Мозамбіку не досягла цілі. Втім, ситуація змінилася внаслідок перемін у самій Москві - лібералізація, перебудова, а потім і розпад СРСР змусила іiі відмовитися від своїх інтересів та припинити дотації союзних режимів. Цей факт спричинив падіння дисципліни в структурах державної влади Мозамбіку, в результаті чого новий президент Й. Чіссано у 1992 р. сів за стіл переговорів з опозицією та розгорнув реформаторський курс. Більше того, 
у 1995 р. країна стала 53-м членом Співдружності нації, не пов'язаним 3

Великобританією до проголошення незалежності (Кальвокоресси, 2003: 260).

Висновки. Отже, наприкінці 1980-х рр. Мозамбік залишався одним 3 найбільш відданих союзників Москви в Африці. Надаючи Мозамбіку допомогу у будівництві збройних сил, радянські лідери прагнули будь-якою ціною утримати його в сфері свого впливу. Серед причин слід вказати, передусім, геополітичні фактори, а саме - можливість впливати на сусідню Південну Африку. Крім того, радянський флот мав потребу у базах на західноафриканському узбережжі. Ситуація змінилася внаслідок перемін у самій Москві - лібералізація, перебудова, а потім і розпад СРСР змусила іiі відмовитися від своїх інтересів та припинити дотації союзних режимів.

\section{СПИСОК ВИКОРИСТАНИХ ДЖЕРЕЛ І ЛІТЕРАТУРИ}

Война, которой не было. - Война, которой не было. Мозамбик // URL : https://topwar.ru/106069-voyna-kotoroyne-bylo-mozambik.html (дата звернення: 20.01.2019).

Гриф секретности снят, 1993 - Гриф секретности снят: Потери Вооруженных Сил СССР в войнах, боевых действиях и военных конфликтах: Стат. исслед. / Г. Ф. Кривошеев, В. М. Андроников, П. Д. Буриков. М.: Воениздат, 1993. 452 с.

Договор о дружбе и сотрудничестве - Договор о дружбе и сотрудничестве между СССР и Народной Республикой Мозамбик (Подписан в г. Мапуту 31.03.1977) // URL : https://www.lawmix.ru/abrolaw/15086 (дата звернення: 20.01.2019).

Кальвокоресси, 2003 - Кальвокоресси П. Мировая политика. 1945-2000. Кн. 2. М.: Междунар. отношения, 2003. $448 \mathrm{c.}$

Коломнин, 2005 - Коломнин С.А. Русский спецназ в Африке. М.: Яуза, 2005. 264 с

Крисенко - Крисенко Д. С. Місце Мозамбіку у протистоянні США та СРСР на півдні Африки (1975 - 1991 рр.) // URL : https://www.google.com.ua/ (дата звернення: 22.01.2019).

Лавреинов, Попов, 2005 - Лавреинов С.Я., Попов И.М. Советский Союз в локальных войнах и конфликтах. М.: АСТ: Астрель, 2005. 778 с.

Россия и СССР, 2001 - Россия и СССР в войнах ХХ века: Статистическое исследование. М.: ОЛМА-ПРЕСС, 2001. $608 \mathrm{c}$.

Россия (СССР) в локальных войнах, 2000 - Россия (СССР) в локальных войнах и вооруженных конфликтах второй половины XX века / Под ред. В. А. Золотарева. М.: Кучково поле; Полиграфресурсы, 2000. 576 с.

Шарый, 2008 - Шарый В. И. Помощь СССР в создании вооружённых сил Народной Республики Мозамбик. 1964 - 1991 гг. // Военно-исторический журнал. 2008. № 11. С. 18-20.

Шарый - Шарый В. И. Военное сотрудничество советского Союза с бывшими португальскими колониями в 70 80 гг. XX века // URL : https://cyberleninka.ru/article/n/voennoe-sotrudnichestvo-sovetskogo-soyuza-s-byvshimiportugalskimi-koloniyami-v-70-80-gg-hh-veka (дата звернення: 22.01.2019).

Шинкарёв, 1989 - Шинкарёв Л. И. Горький дым Саванны. М.: Советская Россия, 1989. 368 с.

\section{REFERENCES}

Voyna, kotoroy ne bylo. - Voyna, kotoroy ne bylo. Mozambik [War, which was not. Mozambique.] // URL : https://topwar.ru/106069-voyna-kotoroy-ne-bylo-mozambik.html (20.01.2019) [in Russian].

Grif sekretnosti snyat, 1993 - Grif sekretnosti snyat: Poteri Vooruzhennykh Sil SSSR v voynakh, boevykh deystviyakh i voennykh konfliktakh [The stamp of secrecy is removed: Loss of the Armed Forces of the USSR in wars, hostilities and military conflicts]: Stat. Issled. / G. F. Krivosheev, V. M. Andronikov, P. D. Burikov. M.: Voenizdat, 1993.452 s. [in Russian]. 
Dogovor o druzhbe i sotrudnichestve - Dogovor o druzhbe i sotrudnichestve mezhdu SSSR i Narodnoy Respublikoy Mozambik (Podpisan v g. Maputu 31.03.1977) [Treaty of Friendship and Cooperation between the USSR and the People's Republic of Mozambique (Signed in Maputo 03/31/1977)] // URL : https://www.lawmix.ru/abrolaw/15086 (20.01.2019) [in Russian].

Kalvokoressi, 2003 - Kalvokoressi P. Mirovaya politika. 1945-2000 [Global politics. 1945-2000.]. Kn. 2. M.: Mezhdunar. otnosheniya, 2003. 448 s. [in Russian].

Kolomnin, 2005 - Kolomnin S.A. Russkiy spetsnaz v Afrike [Russian special forces in Africa]. M.: Yauza, 2005.264 s. [in Russian].

Krysenko - Krysenko D. S. Mistse Mozambiku u protystoianni SShA ta SRSR na pivdni Afryky (1975 - 1991 rr.) [The place of Mozambique in the confrontation between the United States and the USSR in southern Africa (1975-1991)] // URL : https://www.google.com.ua/ (22.01.2019) [in Russian].

Lavreinov, Popov, 2005 - Lavreinov S.Ya., Popov I.M. Sovetskiy Soyuz v lokalnykh voynakh i konfliktakh [Soviet Union in local wars and conflicts]. M. : AST: Astrel, 2005. 778 s. [in Russian].

Rossiya i SSSR, 2001 - Rossiya i SSSR v voynakh XX veka: Statisticheskoe issledovanie [Russia and the USSR in the wars of the XX century: Statistical research]. M.: OLMA-PRYeSS, 2001. 608 s. [in Russian].

Rossiya (SSSR) v lokalnykh voynakh, 2000 - Rossiya (SSSR) v lokalnykh voynakh i vooruzhennykh konfliktakh vtoroy poloviny XX veka [Russia (USSR) in local wars and armed conflicts of the second half of the XX century] / Pod red. V. A. Zolotareva. M.: Kuchkovo pole; Poligrafresursy, 2000. 576 s. [in Russian].

Sharyy, 2008 - Sharyy V. I. Pomoshch SSSR v sozdanii vooruzhennykh sil Narodnoy Respubliki Mozambik. 1964 $1991 \mathrm{gg}$. [USSR assistance in the creation of the armed forces of the People's Republic of Mozambique. 1964 1991]Voenno-istoricheskiy zhurnal. 2008. № 11. S. 18-20. [in Russian].

Sharyy - Sharyy V. I. Voennoe sotrudnichestvo sovetskogo Soyuza s byvshimi portugalskimi koloniyami v 70-80 gg. KhKh veka [Military cooperation of the Soviet Union with the former Portuguese colonies in 70-80 years XX century] // URL : https://cyberleninka.ru/article/n/voennoe-sotrudnichestvo-sovetskogo-soyuza-s-byvshimi-portugalskimikoloniyami-v-70-80-gg-hh-veka (22.01.2019) [in Russian].

Shinkarev, 1989 - Shinkarev L. I. Gorkiy dym Savanny [Bitter smoke Savannah]. M.: Sovetskaya Rossiya, 1989. 368 s. [in Russian]. 